(C) 2014

\author{
Мірзаєва М. С., аспірант
}

(Науковий керівник - доктор ветеринарних наук С. М. Кулинич)

Полтавська державна аграрна академія

\title{
ЕФЕКТИВНІСТЬ ЛОКАЛЬНОГО ЗАСТОСУВАННЯ КОЛОЇДУ НАНОКЛАСТЕРІВ АКВАХЕЛАТІВ МЕТАЛІВ (АG, СU, ZN, MG) ЗА ЛІКУВАННЯ ПАРОДОНТОПАТІЙ У СОБАК
}

\section{Рецензент - доктор ветеринарних наук А. А. Замазій}

У роботі висвітлені в динаміці результати окремих морфологічних показників кревікулярної рідини в порівнянні за застосування 10 \%-го колоїду нанокластерів аквахелатів металів ( $\mathrm{Ag}, \mathrm{Cu}, \mathrm{Zn}, \mathrm{Mg}$ ) та хлоргексидину біглюконату $(0,05 \%$-й розчин) у лікуванні клінічно хворих собак на ранні форми пародонтопатій. Встановлюючи порівняльну ефективність співставляли кількісно та якісно динаміку десквамованого плаского епітелію й форми лейкоичитів. У проиесі локального застосування колоїду нанокластерів реєстрували поступову нормалізацію даних показників.

Ключові слова: собака, кревікулярна рідина, десквамований плаский епітелій та форми лейкоцитів.

Постановка проблеми. У ветеринарній стоматології хвороби пародонту домінують за своєю інтенсивністю, поширенням і руйнівними наслідками для зубощелепної системи тварин. У зв'язку з цим на сучасному етапі розвитку ветеринарії постала проблема пошуку ефективних методів лікування запальних захворювань пародонту у собак $[4,6,16]$. Одним із таких методів місцевого лікування $\epsilon$ застосування нанокластерів аквахелатів металів $[3,5,8,10,11]$.

Аналіз останніх досліджень i публікацій, у яких започатковано розв'язання проблеми. До нинішнього часу одним із основних препаратів для місцевого лікування пародонтопатій залишався хлоргексидин біглюконат [12]. Однак нерідко за його використання виявляються такі ускладнення як фарбування емалі зубів, підвищене відкладення назубного каменю, порушення смаку [17].

На сьогодні у ветеринарній медицині накопичений досить значний статистичний матеріал щодо лікування захворювань пародонту у собак $[4,6,16]$, проте ще недостатньо уваги звертається на впровадження новітніх препаратів для лікування даної патології, зокрема нанокластерам аквахелатів металів, які все частіше застосовують практикуючі лікарі $[3,5,8,14]$.

Серед переваг, характерних для наноречовин, слід виділити їхню біологічну сумісність та екологічну чистоту, завдяки яким можна значно розширити спектр застосування продуктів нанотехнології у різних галузях ветеринарної медицини [7].

Пошук методів лікування та профілактики хвороб тварин заснований на застосуванні наночасток металів і має важливий науковий і практичний інтерес [13].

Мета дослідження: встановити ефективність використання нанокластерів аквахелатів металів $(\mathrm{Ag}, \mathrm{Cu}, \mathrm{Zn}, \mathrm{Mg})$ за лікування клінічно хворих собак на ранніх стадіях пародонтопатій.

Завдання дослідження: оцінити порівняльну ефективність проведеного локального лікування за допомогою кількісного та якісного підрахунку окремих морфологічних показників: десквамованого плаского епітелію та форм лейкоцитів у кревікулярній рідині в динаміці.

Матеріали і методи. Для встановлення ефективності препаратів було сформовано дві групи тварин. У контрольній групі $(\mathrm{n}=5)$ локально застосували хлоргексидин біглюконат $(0,05 \%$-й розчин), а в дослідній (n=3) локально використали $10 \%$-й колоїд нанокластерів аквахелатів металів (Ag, $\mathrm{Cu}, \mathrm{Zn}, \mathrm{Mg})$ [11].

Постановку досліду проводили на собаках різних порід віком від 4-х до 12-и років, за десятиденного контролю показників тріасу. У собак обох груп відбирали зразки кревікулярної рідини вранці натще серце.

Проби субстрату для морфологічних досліджень отримували за методиками С. В. Єриної, С. Я. Дячкової, а також Е. Н. Жулева, А. Б. Сєрова $[2,9]$, адаптованими нами шляхом взяття зразків із пародонтальних кишень 3 апроксимальних поверхонь іклів та премолярів з ознаками пародонтопатій за допомогою стерильних ендодонтичних паперових штифтів ISO 30 (Meta Biomed, United Kindom). Оточуючi тканини попередньо осушували стерильними марлевими тампонами, 10 штифтів вводили до дна кишені й залишали там на 5 хвилин. Далі штифти переносили у пробірку ємкістю 200 мкл із фізіологічним розчином натрію хлориду (200 мкл), зали- 


\section{СТОРІНКА МОЛОДОГО ВЧЕНОГО}

шали на 30 хв. для вимивання іiі компонентів, після чого штифти виймали і впродовж двох годин проводилися дослідження (для уникнення руйнування матеріалу).

Для кількісного підрахунку кревікулярну рідину розводили в розчині $\mathrm{NaCl}$, поміщали в розчин Тюрка у співвідношенні 10:1, після чого перемішували й вносили в камеру Горяєва. Клітинні елементи підраховували по всій площі сітки камери [15]. У процесі якісного підрахунку розведену кревікулярну рідину у фізіологічному розчині натрію хлорид фіксували на склі й фарбували методом Романовського-Гімзи. Підраховували кількість десквамованого плаского епітелію, а також диференціювали форми лейкоцитів по всій площі предметного скла $[1,9]$.

Після седації тварин у них видаляли назубні відкладення за допомогою ультразвукового скейлера (WOODPECKER, КНДP), а далі проводили полірування зубів за допомогою косметичного стоматологічного прибору Dental Polisher, (Profi White, КНДР).

Після закінчення процедури ротову порожнину аерозольно обробляли: в контрольній групі 0,05\%-м розчином хлоргексидину біглюконату (КП «Луганська обласна «Фармація», Україна), а в дослідній 10 \%-м колоїдом нанокластерів аквахелатів металів (Ag, $\mathrm{Cu}, \mathrm{Zn}, \mathrm{Mg})$.

Дослідження проб кревікулярної рідини проводили: перший раз - до ультразвукової очистки зубів та до першого розпилення розчинів в обох групах, вдруге - на шосту, а третій раз - на сімнадцяту добу. Ротову порожнину обробляли щоденно один раз.

Отриманий експериментальний матеріал опрацьовували методом варіаційної статистики 3 визначенням середніх арифметичних (М) і стандартних відхилень (m), з урахуванням вірогідного інтервалу за наявного рівня значимості $\mathrm{p}<0,05, \mathrm{p}<0,001$, а також за критерієм вірогідності Стьюдента між контролем і дослідом між першою та шостою, першою і сімнадцятою добами.

Результати досліджень. Результати проведених лабораторних досліджень свідчать, що за кількісного підрахунку морфологічного складу кревікулярної рідини від клінічно хворих собак у дослідній групі на першу добу кількість пласко-

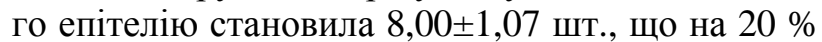

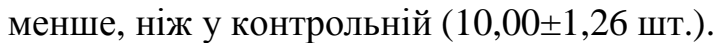

На шосту добу показник у контрольній групі

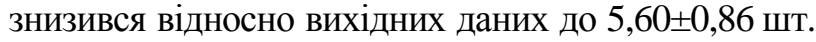
i був менший на $30,0 \%$, ніж у дослідній

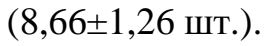

На сімнадцяту добу в контролі кількість плаского епітелію була більша на $33,4 \%$, ніж у до-

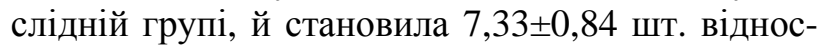
но вихідних даних.

Кількість лейкоцитів у контрольній групі стано-

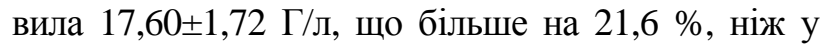
дослідній.

На шосту добу кількість лейкоцитів у контролі збільшилася відносно вихідних даних до

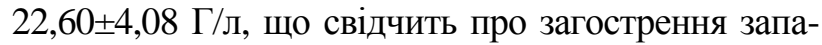
льного процесу в ротовій порожнині й на

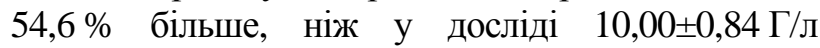
$(\mathrm{p}<0,05)$.

До останньої доби лікування в дослідній групі

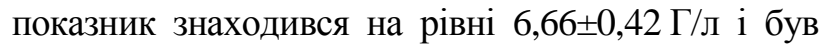
меншим на 39,5 \%, ніж у контрольній (див. табл.).

Динаміка морфологічного складу кревікулярної рідини у клінічно хворих собак на ранні форми пародонтопатій $(M \pm m)$

\begin{tabular}{|c|c|c|c|c|c|c|}
\hline \multirow{2}{*}{ Показник } & \multicolumn{7}{|c|}{ Тварини } \\
\cline { 2 - 7 } & \multicolumn{2}{|c|}{1 -а доба } & \multicolumn{2}{|c|}{6 -а доба } & \multicolumn{2}{c|}{17 -а доба } \\
\cline { 2 - 7 } & $\mathrm{K}=5$ & $\begin{array}{c}\text { Д } \\
\mathrm{n}=3\end{array}$ & $\begin{array}{c}\mathrm{K}=5 \\
\mathrm{n}=3\end{array}$ & $\begin{array}{c}\text { К } \\
\mathrm{n}=5\end{array}$ & $\begin{array}{c}\text { Д } \\
\mathrm{n}=3\end{array}$ \\
\hline $\begin{array}{c}\text { Плаский епітелій, } \\
\text { шт. у камері }\end{array}$ & $8,00 \pm 1,07$ & $10,00 \pm 1,26$ & $5,60 \pm 0,86$ & $8,66 \pm 1,26$ & $11,40 \pm 3,00$ & $7,33 \pm 0,84$ \\
\hline $\begin{array}{c}\text { Лейкоцити, } \\
\text { Гл у камері }\end{array}$ & $17,60 \pm 1,72$ & $13,33 \pm 1,26$ & $22,60 \pm 4,08$ & $10,00 \pm 0,84^{*}$ & $11,60 \pm 2,36$ & $6,66 \pm 0,42$ \\
\hline $\begin{array}{c}\text { Плоский епітелій, } \\
\text { шт. у мазку }\end{array}$ & $14,80 \pm 3,86$ & $18,33 \pm 1,26$ & $9,60 \pm 2,80$ & $10,33 \pm 0,42$ & $13,80 \pm 1,29$ & $11,33 \pm 0,42$ \\
\hline $\begin{array}{c}\text { Лімфоцити, } \\
\text { шт. у мазку }\end{array}$ & $4,40 \pm 0,21$ & $4,33 \pm 0,42$ & $8,80 \pm 1,50$ & $4,00 \pm 0,84^{*}$ & $4,00 \pm 0,43$ & $3,66 \pm 0,42$ \\
\hline $\begin{array}{c}\text { Нейтрофіли, } \\
\text { шт. у мазку }\end{array}$ & $15,00 \pm 1,29$ & $16,33 \pm 1,26$ & $5,40 \pm 1,72$ & $11,66 \pm 0,42^{*}$ & $6,40 \pm 0,64$ & $11,00 \pm 0,42^{* * * *}$ \\
\hline
\end{tabular}

Примітка: * - p<0,05, *** - p<0,001, де р відносно контролю 


\section{СТОРІНКА МОЛОДОГО ВЧЕНОГО}

Результати досліджень кількості плаского епітелію й лейкоцитів на сімнадцяту добу вказують на тенденцію до зниження показників у дослідній групі відносно контрольної, що свідчить про більшу ефективність використання нанокластерів, оскільки лейкоцитарна активність і збільшена кількість плаского епітелію в кревікулярній рідині є маркерами запалення.

У процесі якісного підрахунку клітинних елементів показники плаского епітелію на першу добу в дослідній групі були на 17,8 \% вищими, ніж у контрольній. До шостої доби зазначений показник збільшився на 4 \% у дослідній групі (10,33 $\pm 0,42$ шт.) відносно контрольної $(9,60 \pm 2,80$ шт.). На сімнадцяту добу в контрольній групі кількість плаского

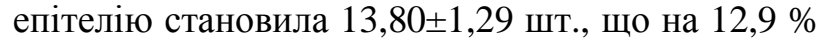
більше, ніж у дослідній. Слід зазначити, що лімфоцити як у контрольній, так і у дослідній групах залишалися на одному рівні. На шосту добу в контролі показник був на $50 \%$ більшим $(8,80 \pm 1,50$ шт.), ніж у досліді $(4,00 \pm 0,84$ шт., $\mathrm{p}<0,05)$, відносно вихідних даних. На сімнадцяту добу у контрольній групі було більше на 8,5 \% лімфоцитів, аніж у дослідній.Слід зазначити, що в процесі терапії кількість нейтрофілів по всій площі мазка в дослідній групі на першу добу становила

\section{БІБЛІОГРАФІЯ}

1. Борисов Л. Б. Микробиология и иммунология стоматологических заболеваний / Л. Б. Борисов, И. С. Фрейдлин // В кн.: Медицинская микробиология, вирусология, иммунология / Под ред. Л. Б. Борисова, А. И. Смирновой. - М. : Медицина, 1994. - С. 496-522.

2. Ерина С. В. Цитологическое исследование десневой жидкости при заболеваниях пародонта / С. В. Ерина, С. Я. Дьячкова // Лабораторное дело. - 1989. - №6. - С. 14-15.

3. Здобутки нанотехнології в лікуванні та профілактиці хвороб тварин. Нановетеринарія (впровадження інноваційних технологій) / Борисевич В. Б., Борисевич Б. В., Хомин Н. М. [та ін.]; Під ред. В. Б. Борисевича. - К. : Діа, 2009. $182 \mathrm{c}$.

4. Ільніцький М. Г. Поширеність хвороб пародонту у собак / Микола Ільніцький, Дмитро Арсеєнко // Вісник Білоцерків. держ. аграр. ун-ту. 2006, № 41. - C. 55-61.

5. Каплуненко В. Г., Косинов Н. В., Поля$к о в$ Д. В. Получение новых биогенных и биоцидных наноматериалов с помощью эрозионновзрывного диспергирования металлов: Сборник трудов по материалам научно-практических конференций с международным участием «Нанотехнологии и наноматериалы для биологии и
16,33 1,26 шт., що на 6,3\% більше, ніж у контрольній. На шосту добу у контролі відносно ви-

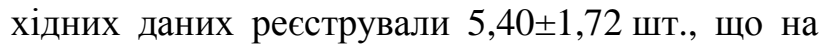
$51,0 \%$ менше, ніж у досліді $(11,66 \pm 0,42, \mathrm{p}<0,05)$. На сімнадцяту добу у дослідній групі кількість

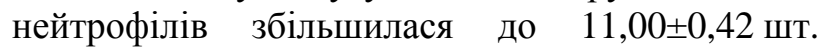
( $<<0,001)$, переважаючи на 41,8 \% контроль.

Висновки: 1.У процесі локального застосування колоїду нанокластерів аквахелатів металів у процесі лікування клінічно хворих собак на ранні форми пародонтопатій реєструється поступова нормалізація кількісно та якісно десквамованого плаского епітелію та форм лейкоцитів, які входять до клітинного складу кревікулярної рідини, на відміну від показників у разі застосування розчину хлоргексидину біглюконату (0,05\%-го розчину), що свідчить про затухання запальної реакції.

2. Подальші дослідження та використання у хірургічній практиці вище зазначених показників дадуть змогу більш інформативно діагностувати й патогенетично обгрунтовано провести лікування пародонтопатій на ранніх стадіях захворювання.

медицины», 11-12 октября 2007 г. - СибУПК. Новосибирск, 2007. - С. 134-137.

6. Касумов М. В. Хирургическая патология ротовой полости у собак: новые методы диагностики: автореф. дис. ... канд. вет. наук : спец. 16.00 .05 «Ветеринарная хирургия», 03.00 .13 «Фізіологія людини і тварини» / М. В. Касумов. СПб., 2006. - 15 c.

7. Кисель В.П., Трескунов К.А. Микродеформации молекулярных и клеточных структур - ключевой механизм стресса и адаптаций: роль наночастиц в этих процессах // Наночастицы в природе. Нанотехнология в приложении к биологическим системам / Материалы второго Российского научно-методического семинара. М. : Аквариум Принт, 2005. - С. 70-71.

8. Нанотехнологія у ветеринарній медицині / Борисевич В. Б., Борисевич Б. В., Петренко О. Ф. [та ін.]; Під ред. В. Б. Борисевича. - К.: Лира, 2009. - $232 \mathrm{c}$.

9. Пат. 2349920 Российская Федерация, МПК (2007) G01N33/68, А61B10/00. Способ исследования десенной жидкости / Жулев Е. Н., Серов А. Б.; заявитель и патентообладатель Нижегородская государственная медицинская академия Федерального агентства по здравоохранению и социальному развитию. - № 2007120235/15; заявл. 30.05.07; опубл. 
20.03.09, Бюл. № 54. - 3 c.

10. Пат. 29852 Україна, МПК (2006): C07F 19/00, С12N 1/20. Аквахелат нанометалу / Косінов М. В., Каплуненко В. Г.; зявник та патентотримач Держ. Департамент інтелекуальної власності. - № U200711779; заява 25.10.07; опубл. 25.01.2008, Бюл. № 1/2008. - 6 c.

11. Пат. 26344 Україна, МПК (2006): В22F 9/00. Спосіб ерозійно-вибухового диспергування металів / Косінов М.В., Каплуненко В.Г.; зявник та патентотримач Держ. Департамент інтелекуальної власності. - № U200706439; заява 11.06.07; опубл. 10.09.2007, Бюл. № 7/2007. - 1 с.

12. Профілакика пародонопатій у собак [Електронний ресурс] / М. Г. Ільніцький, Д. В. Арсеєнко. Режим доступу до журналу: http://vet.okis. $\mathrm{ru} /$ profilparo.html

13. Ратнер M. Нанотехнология: простое объяснение очередной гениальной идеи / М. Ратнер, Д. Ратнер. - М. : Вильямс, 2004. - 240 с.
14. Рашидова С. Ш., Рубан И. Н., Воропаева Н. П. Создание наночастиц и наноструктур в системах на основе природных биополимеров и их применение в биотехнологии, медицине и сельськом хозяйстве // Наночастицы в природе. Нанотехнология в приложении к биологическим системам / Материалы 2-го Российского научнометодического семинара. - М. : Агровет, 2005. C. 9-17.

15. Ронин В. С. Руководство к практическим занятиям по методам клинических лабораторных исследований / Ронин В. С., Старобинец Г. М., Утевский Н. Л. - М. : Медицина, 1989. - 318 с.

16. Стоматология собак / Фролов В. В., Волков А. А., Анников В. В. [и др.]. - М. : ООО «Аквариум-Принт», 2006. - 288 с.

17. Хлоргексидин диглюконат [Електронний pecypc] http://www.webapteka.ru/drugbase/ name11194.html 